\title{
An investigation on daylighting performance in educational institutions
}

\author{
Tuğba İnan \\ Department of Architecture, Izmir Institute of Technology, Izmir, Turkey
}

\begin{abstract}
Purpose - The purpose of this research is to investigate natural illumination properties of one of the classrooms in the School of Architecture at Izmir Institute of Technology, located in Turkey, which is the northern hemisphere.

Design/methodology/approach - In this study, the definitions of the basic terms in daylighting, such as daylight factor, illuminance, glazing ratio, are given first. Then, a luxmeter and a lighting simulation software, Velux, are used in order to calculate variable lighting factors during daytime, at different storeys, at different directions, for the classes. Velux is a proprietary software and it enables natural lighting analysis practically.

Findings - Chosen classrooms are examined regarding their having sufficient natural illumination. The height of windows from the floor is changed, and the resultant effects on natural lighting in the classrooms are determined by using the lighting simulation program, Velux. The study shows that daylight factor and illumination near the window decreases as the height of the window above the floor increases. However, the illumination increases away from the window, giving greater uniformity to the lighting. At the same time, the usable depth of the classroom increases. The tall and narrow windows bring the daylight near themselves.

Social implications - Practical window design decisions can help architects to provide effective and healthy natural lighting for interiors.

Originality/value - Adjustment of the dimensions of the windows is important in order to balance the energy consumption of buildings. This study investigates natural lighting depending on both experimental measurements and simulation software, Velux.
\end{abstract}

Keywords Daylight, Daylight factor, Illumination, Window size, Light, Light distribution, Lighting systems, Windows, Classrooms, Educational institutions

Paper type Research paper

\section{Introduction}

In the context of global warming and decreasing natural energy resources, it is essential to focus on reducing the consumption of energy in buildings especially in educational buildings regarding their working areas and necessity of great lighting energy.

Most fosil fuels are used to generate electricity in buildings (Freewan, 2011). However, the use of such energy resources cause on environmental problems such as climate changes and global warming (Li, 2010). Buildings consume a great amount of energy for heating, cooling and lighting. In residential buildings, while heating is the largest energy consumer, in commercial buildings, lighting is the active energy consumer (US Department of Energy, 2010).

Daylighting is a kind of passive strategy to improve energy performance and users' visual comfort without expensive installation and operational cost (Lim et al., 2012). Daylight is the full-spectrum of light that is most suitable to the human visual response. Thus, it can contribute to human health, performance and productivity (Galasiu and Veitch, 2006; Cheung and Chung, 2008). However, in some conditions, daylight may cause glaring problems especially in workplaces or any places in the 
SS

31,2

122 visual environment. Solar shading devices control glaring problems and reduce solar gains, and thus avoid overheating (Loutzenhiser et al., 2007; Balocco and Calzolari, 2008).

Daylighting is an effective factor in architecture and sustainable strategy in energy efficient building design (Ihm et al., 2009). Recently, it has become a significant part of the environmentally friendly building design (Kim et al., 2012). Related literature suggest that it is possible to obtain a considerable reduction in the consumption of electric energy through architectural projects that maximize the usage of natural illumination level (Li et al., 2006; Lee and Selkowitz, 2005; Doulos et al., 2008; Pyonchan et al., 2009; Singh and Garg, 2010; Tíba and Leal, 2012; Kim et al., 2012). Perez et al. (1990) proposed a weather model to define efficiency of luminous and exterior illuminance. For point to point calculation, the illuminance is described based on the daylight factor (DF). This method is used to calculate the average DF of a space rather than at any specific point (Li and Cheung, 2006; Longmore, 1975).

The amount of energy consumption in a building mainly depends on its fenestration system. Windows play a significant role in energy consumption of a building in that they can provide transmitting light indoor environment and allow visual outdoor contact with the building occupants (Li, 2010). The design and selection of a suitable window system can be regarded as one of the most significant strategies for reducing the energy consumption effectively in a building (Lee et al., 2013).

The studies in the literature have focussed on a specific envelope component, issues of glazing applications in building façade connected with problems like overheating, overcooling or glazing (Manz and Menti, 2012; Stegou et al., 2007; Ho et al., 2008; Gueymard and duPont, 2009; Ramos and Ghisi, 2010). Jenkins et al. (2009) focussed on the overheating problems in school buildings. They proposed optimization of these problems with solutions for daylighting to provide sufficient comfort conditions in classrooms (Jenkins et al., 2009). The size of windows has important effects on natural illumination. Large window area provides more daylight into a space and maximum usage of daylight. However, they may also cause excessive heat gains or losses which increase the energy consumption (Ghisi and Tinker, 2005). Narrow window area may not reduce the daylighting performance, but it supports thermal insulation and minimizes the cooling loads ( $\mathrm{Li}, 2010)$. In a room with one-sided window, daylight is likely to be more nearly proportional to the amount of daylight falling on the window, compared to the external horizontal daylight illuminance (Li, 2010). According to BS8206-2, window heads should be above standing eye height, and sills below the eye level of a seated occupant. For a single sided room, if the depth of room from outside wall is lower than $8 \mathrm{~m}$, the percentage of window wall as seen from inside should be minimum 20 percent. When it is equal or between 8 and $11 \mathrm{~m}$, the percentage of window wall should be minimum 25 percent. If it is $>14 \mathrm{~m}$, the percentage of window wall should be 35 percent (BS 8206-2, 2008).

There are various codes (BSI, 1992; BS 8206-2, 2008), regulations (Hong Kong Government, 1997; Buildings Department, HKSAR, 2005) and design handbooks (Illuminating Engineering Society (IES) of North America, 1993) that present the precautions and conditions for good daylighting in buildings. USGBC, LEED-NC (2009), green building rating system from the US Green Building council, suggests a DF of 2 percent for the minimum daylight level and a minimum illuminance level of $269 \mathrm{~lx}$ on the equinox at 9 a.m. and 3 p.m. under the International Commission on Illumination (CIE) clear sky conditions. The environmental rating system BREEAM awards a credit where occupied spaces have an average DF of over 2 percent. The Illuminating Engineering Society of North America (IESNA, 2011) committee promotes 
an illuminance level of $300 \mathrm{~lx}$ for offices, classrooms and library type spaces, occupied hours from 8 a.m. to 6 p.m. local clock time. Uniformity in the illuminance is a significant criterion in daylighting. General guidelines tend to include an illuminance uniformity criterion (e.g. minimum to average of 0.7 over the area of work). According to Chartered Institution of Building Services Engineers (CIBSE), in educational buildings, the minimum illuminance level is $300 \mathrm{~lx}$ for classrooms and computer practice rooms whereas the minimum illuminance level is $750 \mathrm{~lx}$ for technical drawing classrooms and 500 lx for conference and meeting rooms (Chartered Institution of Building Services Engineers (CIBSE), 2006).

This study investigates the feasibility of fitting windows in order to maximize the usage of daylighting. To find solutions to maximize the daylighting performance and to decrease the artificial costs, windows size and their orientation on the façade are analyzed through measurements and a series of computer simulations by Velux. The results of this study will be evaluated in terms of illumination levels and DF of the classrooms according to the legislations and standarts related to daylighting.

\section{Theoretical background}

\subsection{Basic terms related to illumination}

2.1.1 Illumination (E). Illumination is a deprecated term for illuminance. Illuminance is the result of illumination on a lighted surface and is defined as the luminous flux falling on a unit area of the surface under consideration. An imaginary surface can, for example, be used to measure or calculate illuminance anywhere in space, maybe to determine the DF on the workplane. Standard unit for illuminance is lux which is lumens per square meter $\left(\mathrm{lm} / \mathrm{m}^{2}\right)$ :

$$
E=\frac{F}{A}
$$

where $E$ is illuminance of a surface $\left(1 \mathrm{~m} / \mathrm{m}^{2}\right.$ or $\left.1 \mathrm{x}\right), F$ is luminous flux incident on the surface (lumen) and $A$ is the area of the surface $\left(\mathrm{m}^{2}\right)$.

2.1.2 DF. Daylight can be handled quantitatively in two ways:

(1) By using luminous quantities (flux, illuminance), i.e. by a set of outdoor conditions and calculating the resulting interior illuminances.

(2) By using relative values (the DF) which compare indoor to outdoor regarding illuminance. For a given position, this factor is constant under widely varying outdoor lighting conditions.

Lighting design for illumination normally takes into consideration diffuse light only. The most common metric for measuring daylight - the DF - is valid under the CIE overcast sky model.

The DF is defined through the relation between the indoor illuminance at a point on working plane, $E_{i}$ and the outdoor horizontal illuminance, $E_{o}$, for a CIE overcast sky conditions (Commission Internationale de l'Eclairage (CIE), 1970):

$$
\mathrm{DF}=\left(\frac{E_{i}}{E_{o}}\right) \times 100 \%
$$

The DF depends on various parameters such as size and orientation of the glazing, the dimensions of the space, the reflectance of the surfaces and the external 
SS

31,2

124

obstruction. If the space has an average DF of 5 percent or more, it will not normally need electric lighting. If it is below 2 percent, it will need more electric lighting (Building Bulletin 90, 1999).

Mardaljevic et al. (2011) states that only few countries define or recommend specific daylight levels utilizing by average DF. According to the British Lighting Guide (CIBSE, 2006), an average DF of 5 percent or more will ensure that an interior looks substantially daylight whereas an average DF below 2 percent generally makes a room look dull so that electric lighting will most likely be in frequent use (BS 8206-2, 2008).

\subsection{Window effects on daylight}

Windows are valuable particularly for the daylight they deliver and the view they provide. Windowless places, where the space is small, are generally disliked and sometimes illegal. Windows are generally seen attractive with daylight, ventilation and view out. They also give information about the passage of time and weather conditions.

Windows have a significant effect on environmental factors, such as thermal comfort, fresh air supply, energy efficiency and noise intrusion. Therefore, windows can be regarded as a complex part of building design and need to be considered carefully (Building Bulletin 90, 1999).

Daylight is the most obvious vehicle for energy saving in buildings is in exploiting the most abundant source of light available to us. Designers and architects should be aware of that daylight is an important commodity and should consider this fact during the initial part of the design phase.

Windows can be accepted as the eyes of a building. It is an opening in a wall or sides of a building which admits light and often air to the interior. The history of architecture is synonymous with the history of the window and of daylighting from the initial crude openings, letting in light and air, heat and cold. Window is a vehicle for the introduction of daylight, and ultimately to the wondrous interiors of the mediaeval cathedral, the Baroque churches or many private buildings of the eighteenth century.

The window size and disposition are the two most complicated design parameters, since they must incorporate all the human factors such as the provision of view, control of heat gain and loss and the elimination of glare, as well as the more obvious needs of functional vision. Sufficient daylight is generally only available up to a distance of twice the height of the window head height above the working plane into a room (CLEAR, 2012).

Zain et al. (2002) studied on the impact of window geometry on daylighting for Malaysian tropical climate. Their findings revealed that the optimum opening for daylight was 25 percent of window-to-wall ratio. Ne'eman and Hopkinson (1970) state that the combined windows should provide an average 5 percent DF for a substantial part of the floor space. From the architect's viewpoint, this may appear to be the most important decision in determining the appearance of the building elevations from the exterior. On the other hand, from a strategic point of view, it will determine the success of the daylight-based design approach.

Window has developed over the centuries, but its purpose of letting in daylight has remained as its primary role. Window openings require a suitable infill to modify the external climate. At first various materials such as thin slabs of marble, sheets of mica or oiled paper were used. However, it was not until the development of glass that substantial progress could really be made.

The effects of windowless schools received much more attention by researchers. Collins (1975) mentioned several studies supporting windowless schools on the basis of 
practical and economic advantages. The shape and position of windows affects the distribution of daylight into the building. While wide shallow windows provide a broad distribution, tall narrow windows make a deep but narrow distribution (Building Bulletin 90, 1999). Several of these studies argue that the large windows found in most schools in Britain and the USA cause serious problems of overheating and glare on warm and sunny days. Moreover, the use of daylight from side windows as the primary source of illumination resulted in an inflexible style of classroom arrangement reducing the potential usable classroom space (Figueiro et al., 2004).

Ne'eman and Hopkinson (1970) determined that acceptable window width was directly proportional to a participant's distance from the window (i.e. the further one sat away from the window the wider one preferred the window). They find a window value of 35 percent of window wall. Similarly in Keighley's (1973) study windows occupying 10 percent or less of the window wall were regarded as extremely unsatisfactory. The size of windows $<20$ percent of the wall were too small. However, it was acceptable. The result of the study suggest that 20-30 percent is appropriate for the satisfactory of the building occupants.

Fontoynont and Berrutto (1997) state that the ratio of the glazed area to the floor area is called as glazing ratio. Besides, this ratio approximately ranges from 5 to 30 percent. This is a practical idea for an understanding of general brightness of the space over the year. When the windows are confined to one-sided only, it is recommended that the total widths of the windows should be at least 35 percent of the length of the wall (BS 8206-2, 2008).

2.2.1 Design consideration. 2.2.1.1 Environmental factors. Daylight design is related to various environmental factors. It cannot be considered alone. By the suitable choice of window orientation and windows size, many problems can be prevented beforehand. This choice is important in terms of the efficient environment for the type of tasks and activities to be performed. The amount of light entering to the building should neither be too low nor high with regard to the occupant comfort and energy issues.

2.2.1.2 Fenestration. Lighting conditions in a room primarly depend on fenestration. Aybar (2003) states that DF and consequently the illumination near the window decreases as the height of the base of the window above the floor increases. However, the illumination increases away from the window, it gives greater uniformity to the lighting. Lee defines that below the following points should be considered in the design of fenestration:

(1) The window head should be as high as possible (exp. at least $2 \mathrm{~m}$ above floor level, to enable one to see out when standing).

(2) The window sill should not be higher than $1 \mathrm{~m}$ from level to enable one to see out when sitting.

(3) The window surface area should be evenly distributed over the outside wall and the window heights and widths should not be too small in relating to the window wall because this reduces the uniformity of lighting and produces undesirable shadows.

(4) Better lighting can be achieved with windows on opposite walls since the illumination produced by the individual windows are superimposed. The region with the minimum daylighting factor is then displaced towards the centre of the room. The useable depth of the room thus increases and consequently the illumination increases.

\section{Daylighting performance}

125 
SS

31,2

126

Fontoynont and Berrutto (1997) states that the first consideration in daylighting is the size of the window depending on the space to be lit. He defines a formula to have a rapid idea of the general brightness of the space over the year, which is the ratio of glazed area to the floor area. It is typically at a range from 5 to 30 percent. According to a research in Lawrence Berkeley National Laboratory, for a succesful daylighting design this range should be a rate between 10 and 12.5 percent. Neverthless, according to a finding of Mardaljevic et al. (2009), a window-to-floor ratio of 10 percent (even in a simple room) does not guarantee an adequate spread of illuminance levels (DF) and does not prevent significant differences in luminance ratios, resulting in risk of a sensation of glare.

\section{Material and method}

A variety of daylight performance evaluation techniques based on field measurements and computer simulations were proposed in the past. The main step in designing a building, which benefits from daylight for illuminating its interior, is to obtain information on the amount of daylight available outside the building. The oldest parameter for daylight analysis parameter is the DF (Reinhart and Weissman, 2012). The illuminance levels are conventionally estimated depending on the DF approach through a calculation based on the traditional CIE overcast sky excluding direct sunlight (Hopkinson et al., 1966). The studies conducted after 2001, show a tendency to focus on the development of climate-based daylighting parameters (Nabil and Mardaljevic, 2005; Reinhart et al., 2006; Mardaljevic et al., 2009, IESNA, 2011). In these evaluation techniques, a grid of sensor points are used like the DF measurement. However, daylight performance evaluation also depends on illuminance levels under multiple sky conditions.

\subsection{Simulation software}

The impact of daylight on lighting performance of a building can be examined through daylighting simulations. Loutzenhiser et al. (2007) states that energy simulation programs of buildings can be very effective tools at the design stage to evaluate the daylighting performance by generating parametric studies varying the features of windows and shading devices to optimize the energy performance of a building. There are various simulation tools such as Radiance, Superlite, Adeline, Dialux, Ecotect, Relux, etc., to analyze the illumination levels and DF in a building. However, they seem too sophisticated and complex for designers, architects and engineers to make a fullscale computer simulation and time demanding when different building configurations and design options are taken into consideration. These tools should certainly be used by an experienced user or an expert in the best way (Li, 2010).

Velux is a simple visualization tool as a test prototype of the Daylight. The tool will integrate a simple (user friendly) modeler for defining the room boundaries and window configurations and the output, in addition to luminance and illuminance visualizations (DF on work plane) will also include animation of the light course in the room over a day and a year. The basic roof model, windows or door models, surfaces such as floor, ceiling, walls, orientation and location of the building can be organized in the program. There are three kinds of render in the program: luminance, illuminance and DF. Sky conditions, time of day or year can be given to the program. The program has a library, but it has very limited furniture. The program has two types of render option: iso-value and false (colored) value. The illuminance and luminance value can be taken in every point where you would like to investigate. However, the program does 
not provide information related to the average illuminance or luminance values. It gives point measurements and the average of DF. The CIE overcast sky presents the best performance among all worldwide under fully overcast skies models (Enarun and Littlefair, 1995; Li et al., 2004; Li and Tang, 2008). For this reason, the overcast sky conditions are used in the simulation part of the study.

In this study, the windows of the classrooms are investigated according to its effects on DF and illuminance. The size of windows and orientation are altered with the program and variations in the DF and illuminance value are examined for active using of daylight.

\subsection{Experimental measurements}

In order to calculate variable lighting factors with the changing of the window model, at different daytime, storeys, directions for the classes, a luxmeter, LT-Lutron LX-1108 is used. Long-term data measurement is the most effective method to find reliable daylight illuminance values. In order to find the illumination values in each chosen classes, a room index $(R)$ is calculated as the first step. The room index is the number that describes the ratios of the rooms length, width and height (CIBSE, 2006):

$$
R=\frac{(L \times W)}{H_{\mathrm{m}}(L+W)}
$$

where $L$ is the room length, $W$ is the room width and $H_{\mathrm{m}}$ is the mounting height of fitting from working plane

The result of this calculation will be a number usually between 0.75 and 5 according to the CIBSE Code for Interior Lighting ( 0.75 for small rooms and 5 for large rooms). Based on this room index, the number of points is displayed in Table I. This room index will be used later for dividing into classes an equal areas that should as square as possible.

\section{Results}

The amount of daylight entering in a room mainly depends on window openings. In this study, the design possibilities of windows are investigated for an optimum use of daylight. However, it is challenging to light a classroom via only daylight, because of the depth of the classroom and the different tasks which must be performed in it. This study examines the benefits and problems of both daylight, as light and windows, as the most commonly used tool to deliver daylight. The impacts of daylight are considered with the effects of the size of windows, direction, height and shape. Their effects on DF and illumination are investigated.

With this aim, natural illumination properties of chosen three classrooms have been investigated in the Department of Architecture at B Block in İmir Institute of Technology (Plates 1-3). In order to calculate variable lighting factors with the changing of the window model, at different daytime, storeys, directions for the classes,

Room index

Number of points

Below 1

1 and below 2

2 and below 3

3 and above
Daylighting performance

\section{7}


SS

31,2

\section{8}

Plate 1.

An interior view from the A classroom

Plate 2.

An interior view from the B classroom

Plate 3.

An interior view from the C classroom
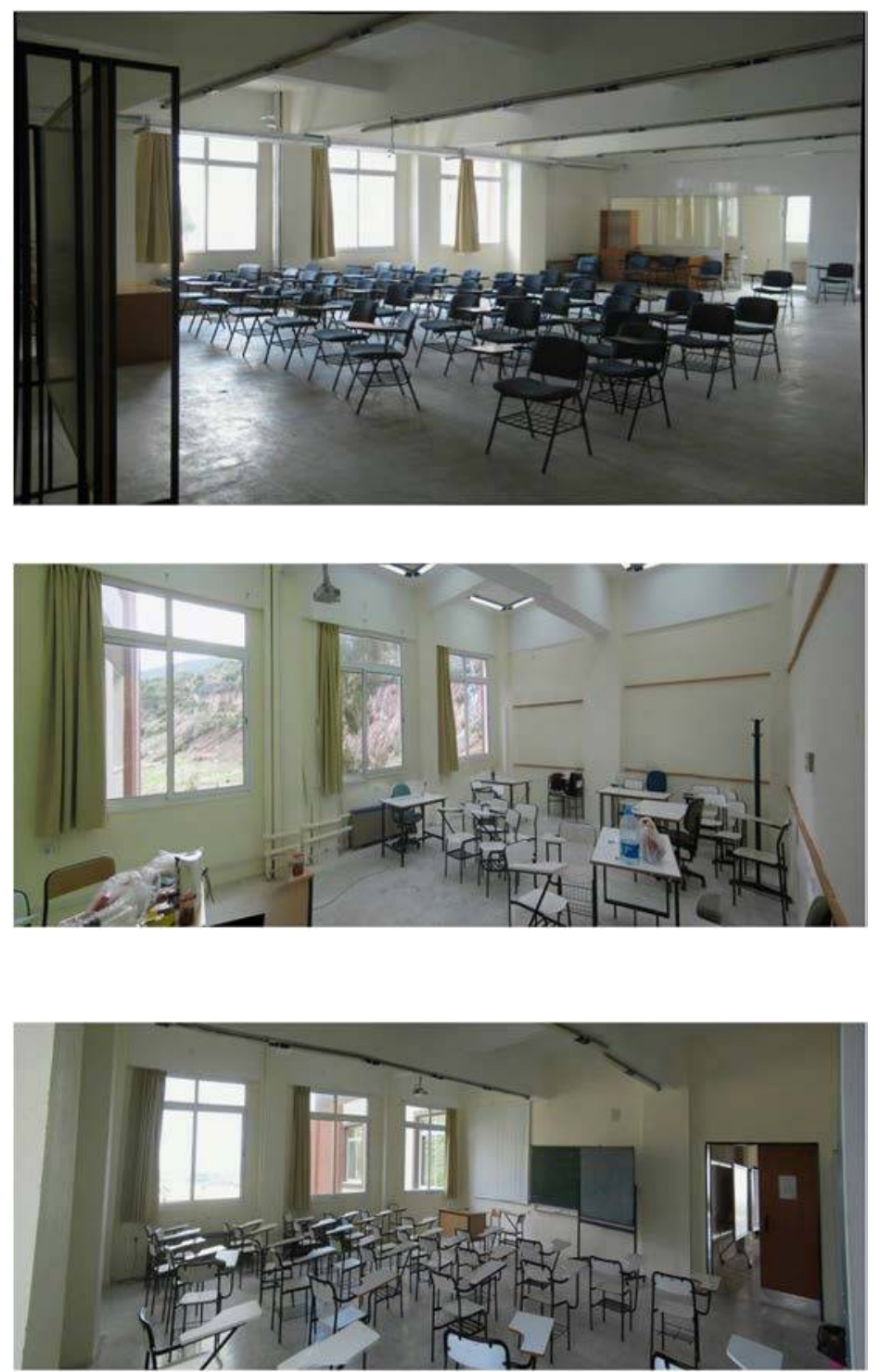

a luxmeter, LT-Lutron LX-1108 and a daylighting simulation software, Velux, have been used. A series of simulations are performed with the simulation program, Velux and the results of these changes on DF and illumination are investigated with Velux.

In the experimental part of the study, the measurement points are arranged in the centre of the grids. The classes locate on different floors with different glazing area. The ground floor, the first floor and the second floor are sequentially coded as A classroom (Figure 1), B classroom (Figure 2) and C classroom (Figure 3), respectively.

In $\mathrm{A}$ and $\mathrm{C}$ classrooms, the room index is found 1.78. Therefore, considering this room index, 16 measurement points are enough for both $\mathrm{A}$ and $\mathrm{C}$ classes. However, the 


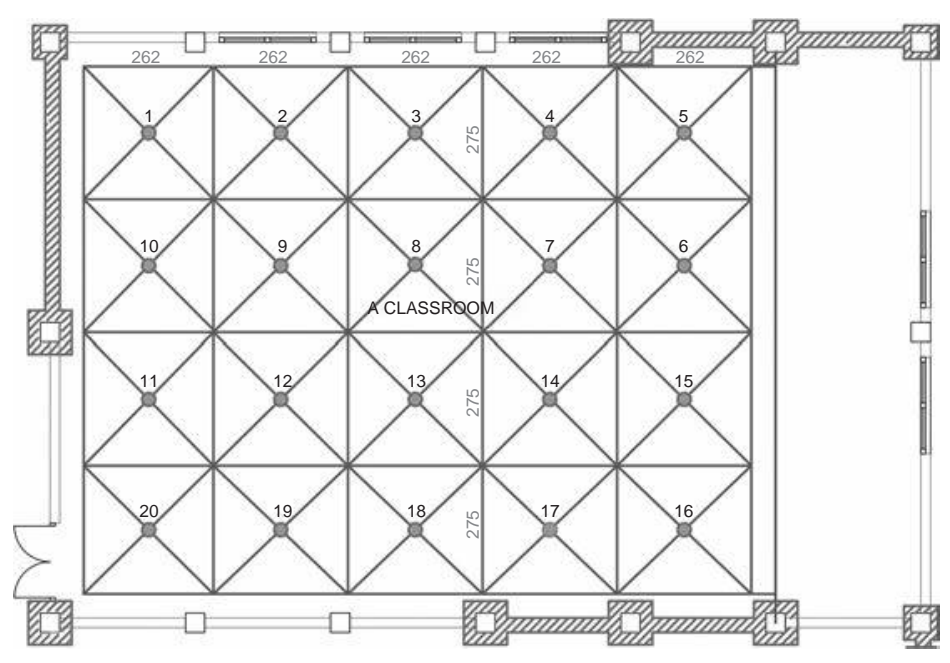

\section{Daylighting performance}

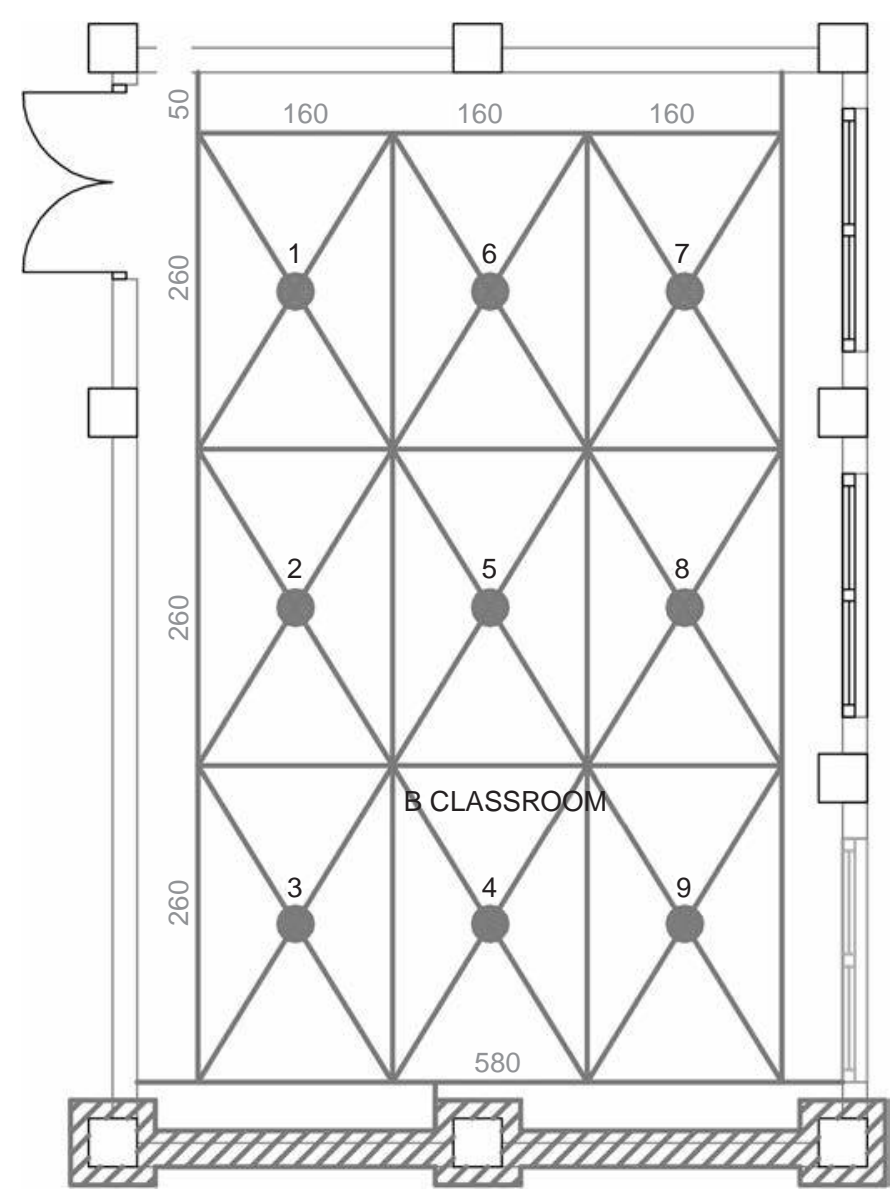

Figure 1.

Measurement points in the A classroom which is located in ground floor

Figure 2.

Measurement points in the $\mathrm{B}$ classroom which is located in first floor 
SS

31,2

130

Figure 3.

Measurement points in the $\mathrm{C}$ classroom which is located in the second floor

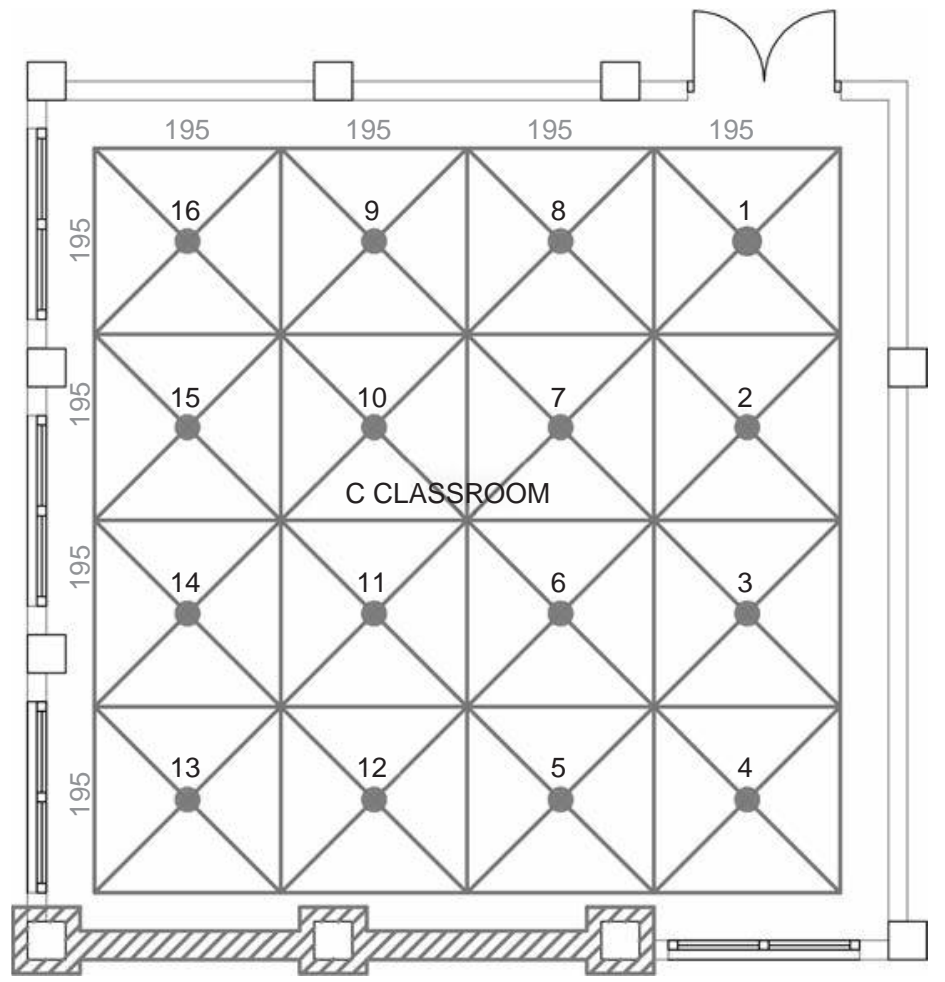

measurement points are taken differently. While 16 points are taken for $\mathrm{C}$ classroom (Figure 3), 20 points are taken in A classroom (Figure 1), because the area in A classroom is larger than in $\mathrm{C}$ classroom. Thus, the aim is to make the measurements clear in A classroom. In B classroom the room index is calculated below 1, therefore nine points are defined for the measurements (Figure 2).

The CIBSE Code recommends that the measurements be taken at least $0.5 \mathrm{~m}$ away from the walls and this must be taken into account in positioning the grid points. This rule is conducted in the chosen classrooms. Illumination levels are determined at the working plane $0.80 \mathrm{~m}$ above the finished floor and at a depth of $4 \mathrm{~m}$. Illumination values are measured in the measurement grid at the centre of the grid where the measurement points are defined. The general information of the classes related to the measurement points are displayed in Table II.

Experimental measurements and a series of simulations are performed with the daylighting software Velux in order to investigate the illumination and DF in the classrooms. The main aim is to examine the windows effects on DF and illuminance. With this aim, first windows height above the floor is altered and its effects on DF and illuminance are investigated with using the simulation software. For this simulation $\mathrm{C}$ classroom is selected. For the simulation overcast sky condition is chosen and 12 o'clock is given to the software to make the simulation of $\mathrm{C}$ classroom.

The glazing ratio in the A classroom is found 10 percent (Table II). This percentage is enough for the illumination according to Lawrence Berkeley National Laboratory. Nevertheless, this is unlikely to result in good values. The brightest points in 


\begin{tabular}{|c|c|c|c|c|}
\hline & A classroom & B classroom & C classroom & Daylighting \\
\hline Classroom length & $1,780 \mathrm{~cm}$ & $880 \mathrm{~cm}$ & $880 \mathrm{~cm}$ & \\
\hline Classroom width & $1,190 \mathrm{~cm}$ & $580 \mathrm{~cm}$ & $880 \mathrm{~cm}$ & \\
\hline Classroom height & $4,000 \mathrm{~cm}$ & $4,000 \mathrm{~cm}$ & $400 \mathrm{~cm}$ & \\
\hline Work surface & 80 & 80 & 80 & \\
\hline Room index & 1.78 & 0.87 & 1.1 & 131 \\
\hline Number of measurement points & 20 & 9 & 16 & \\
\hline Windows width & $200 \mathrm{~cm}$ & $200 \mathrm{~cm}$ & $200 \mathrm{~cm}$ & \\
\hline Windows height & $210 \mathrm{~cm}$ & $210 \mathrm{~cm}$ & $210 \mathrm{~cm}$ & \\
\hline Number of windows & 4 & 3 & 4 & \\
\hline Height of windows above floor & $100 \mathrm{~cm}$ & $100 \mathrm{~cm}$ & $100 \mathrm{~cm}$ & \\
\hline Glazing Area & $5(2.1 \times 2.0)=21 \mathrm{~m}^{2}$ & $3(2.1 \times 2.0)=12.6 \mathrm{~m}^{2}$ & $4(2.1 \times 2.0)=16.8 \mathrm{~m}^{2}$ & \\
\hline Floor area & $206.70 \mathrm{~m}^{2}$ & $51.06 \mathrm{~m}^{2}$ & $76.44 \mathrm{~m}^{2}$ & \\
\hline Glazing ratio & $21 / 206.70 \cong 10 \%$ & $12.6 / 51.06 \cong 24 \%$ & $16.8 / 76.44 \cong 21 \%$ & \\
\hline $\mathrm{E}_{\text {ort }}$ on November 24 at 12 o'clock & $2131 \mathrm{x}$ & $774.61 \mathrm{x}$ & 789.6 & \\
\hline $\mathrm{E}_{\text {ort }}$ on November 24 at 15 o'clock & $147.27 \mathrm{~lx}$ & $296.91 \mathrm{~lx}$ & $374.651 \mathrm{l}$ & \\
\hline $\mathrm{E}_{\text {ort }}$ on November 25 at 9 o'clock & $343.421 \mathrm{x}$ & $5351 \mathrm{x}$ & $432.21 \mathrm{x}$ & \\
\hline$E_{\text {ort }}$ on November 25 at 12 o'clock & $669.691 \mathrm{~lx}$ & $291 \mathrm{~lx}$ & $543.81 \mathrm{x}$ & \\
\hline $\mathrm{E}_{\text {ort }}$ on November 25 at 15 o'clock & $2791 \mathrm{x}$ & $465 \mathrm{~lx}$ & $487 \mathrm{~lx}$ & \\
\hline $\mathrm{E}_{\text {ort }}$ on November 27 at 9 o'clock & $227 \mathrm{~lx}$ & $4061 \mathrm{x}$ & $5791 \mathrm{x}$ & Table II. \\
\hline $\mathrm{E}_{\text {ort }}$ on November 27 at 12 o'clock & $551 \mathrm{~lx}$ & $6631 \mathrm{x}$ & $7661 \mathrm{x}$ & infor \\
\hline $\mathrm{E}_{\text {ort }}$ on November 27 at 15 o'clock & $3131 \mathrm{x}$ & $481 \mathrm{~lx}$ & $6721 \mathrm{x}$ & \\
\hline
\end{tabular}

A classroom are P2, P3, P4 and the darkest points are P11, P19 and P20 (Figure 1). This condition occurs due to the distances of the measurement points from the windows. The ratio between the minimum and average (uniformity ratio) has a range of 0.35-0.40 in the morning, 0.24-0.36 in the midday and 0.21-0.40 in the afternoon. The BREEAM describes a uniformity ratio of at least 0.4. In A classroom, the limit value for illumination uniformity cannot be provided in the midday and in the afternoon. It has a better illumination uniformity in the morning than the other times of the day based on BREEAM. However, the illumination uniformity ratio is defined as 0.7 in CIBSE Code. They are all below this limit in all classes.

The A classroom is located on the ground floor and has windows facing south and west. A classroom has higher illuminance values (550-670 lx) in midday due to its large south windows. In the northern hemisphere, south and west-facing windows both receive a much better quality and quantity of daylight. However, the amount of light entering the room should be controlled by solar shading devices. South-facing window generally receive most sunlight while a north-facing window are able to get the same amount only in the early morning and late evening in summer. South-facing windows can cause excessive heat gain and illuminance variation in time. In the northern hemisphere, the windows facing south provides solar heat gain in winter. Furthermore, the rotation orbit of the sun plays a significant role in the changes of illuminance values. The illumination measurement values of November 24 are lower than the values measured on other days due to the overcast weather effects on illumination. It shows changeable values at the measurement days. Moreover, it presents differences in the same day's illumination measurements because of the weather's deceptive effects on different daytime. For instance, while the average illuminance at 12 o'clock on November 24 displays a value of 213 lx, this value changes to $669.69 \mathrm{~lx}$ at 12 o'clock on November 27. In the measurements, sudden variations in weather conditions are 
SS

31,2

132 observed. Thus, the values of illumination show difference in the same times and at different day's measurement.

The glazing ratio in the B classroom is found 24 percent, which is approximately twice as high as the ratio in the A classroom with its smaller floor area than the $\mathrm{B}$ classroom (Table II). The B classroom faces only one direction as its windows are west facing. Illumination values show rather changeable behavior in three days at each measurement time. The brightest points in $\mathrm{B}$ classroom are P7, P8, P9, and the darkest points are P1, P2 and P3 (Figure 2). The uniformity ratio has a range of 0.33-0.49 in the morning, $0.38-0.51$ in the midday and $0.41-0.57$ in the afternoon. It provides a uniformity of better illumination in the afternoon than the other times of the day.

The B classroom is located on the first floor and it has only west-facing windows. B classroom has higher illuminance values (1,200-1,470 lx) in midday and in the afternoon. West-facing windows receive sunlight in the early afternoon and this light can cause glare problems. The east and west façade windows are exposed to the sunlight directly at specific times of the day, which causes overheating and glare problems.

The glazing ratio in the $\mathrm{C}$ classroom is found 21 percent. This rate is approximate to the value of $\mathrm{B}$ classroom since their floor area and windows areas are close. The classroom C has windows in two directions in which are mostly in east and only a part in the north direction. East windows are good, as sun passes over by class time. Moreover, north windows are better with regard to sky factor. North and east windows maximize the quality and quantity of daylight in the classroom. Therefore, average illumination values are more regular than the other classrooms.

The brightest points in the C classroom are P4, P13, P14, P15, P16 and the darkest points are P1, P2, P7 and P8 (Figure 2). The uniformity ratio has a range of $0.30-0.54$ in the morning, $0.45-0.66$ in the midday and 0.50-0.56 in the afternoon. It provides better illumination uniformity in the midday and afternoon. It is higher than the limit value of 0.4. (BREEAM, 2008). The $\mathrm{C}$ classroom located on the second floor faces with east and north direction windows. C classroom has higher illuminance values (677-857 lx) in midday and in the afternoon.

The height of window from the ground level is a significant factor to provide efficient daylighting. From the simulations, it is observed that the illuminanation values near the window decreases as the height of the window above the floor increases. Nevertheless, the illumination values increase away from the window. Thus, this contributes to increase the usable depth of the classroom (Figures 4-6). It provides uniformity illumination in the classroom.

When the window distance from the ground floor (sill height) is $90 \mathrm{~cm}$, the average DF is 5.28 percent (Figure 4). When it is $150 \mathrm{~cm}$, a DF value of 5.14 percent is observed (Figure 5). If this height is increased, it is noticed that the average DF value decrease. For instance, if it is $160 \mathrm{~cm}$, the average DF decreases to 5.05 percent (Figure 6). According to general mentioned standards and guides, $\mathrm{DF}$ of 2 percent is potential for daylight utilization in educational buildings. Furthermore, the classrooms have more than 5 percent average $\mathrm{DF}$. In all conditions, the $\mathrm{C}$ classroom achieved an average $\mathrm{DF}$ between 5.05 and 5.28. Therefore, these classrooms do not need more electric lighting. They have ideal average DF. On the other hand, it is observed that if window heights get away from the floor level (sill height), the darkest areas decrease (Figures 7-9).

All the models show average illuminances above $500 \mathrm{~lx}$. This is an acceptable illumination value considering all regulations, standards and guides. Moreover, from the results we see that the classrooms with two-side daylighting have the best performances. 

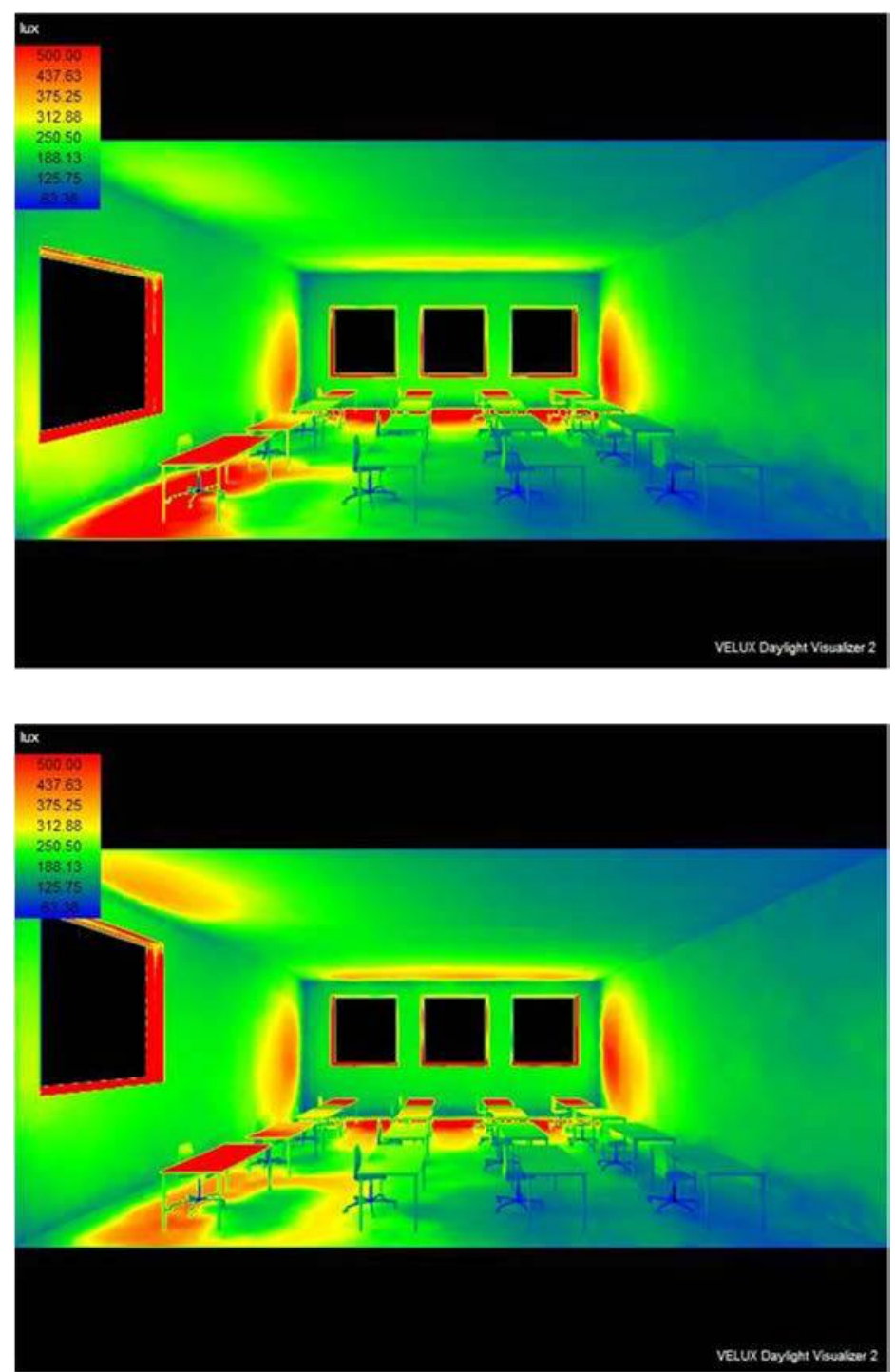

\section{Conclusions}

Daylighting is a promising new technology that has a significant effect on the educational performance of students. If it is properly applied, it can improve the educational environment and can reduce energy usage. The placement and sizing of the windows are among the most significant issues on architectural design for daylight, because, the design of windows has a decisive effect on the daylight performance. It needs to be controlled carefully in the design stage.

Daylight primarily affects the illumination. Different graphs in the paper show the daylight performance of the classrooms based on illumination values and DF. After simulations, it can easily be seen that DF and illumination near the window
Daylighting performance

Figure 4.

Illuminance in the case that height of the window above $90 \mathrm{~cm}$ from floor

Figure 5.

Illuminance in the case that height of the window above $150 \mathrm{~cm}$ from floor 
SS

31,2

134

Figure 6.

Illuminance in the case that height of the window above $160 \mathrm{~cm}$ from floor

Figure 7.

Daylight factor in the case that height of the window above $90 \mathrm{~cm}$ from floor
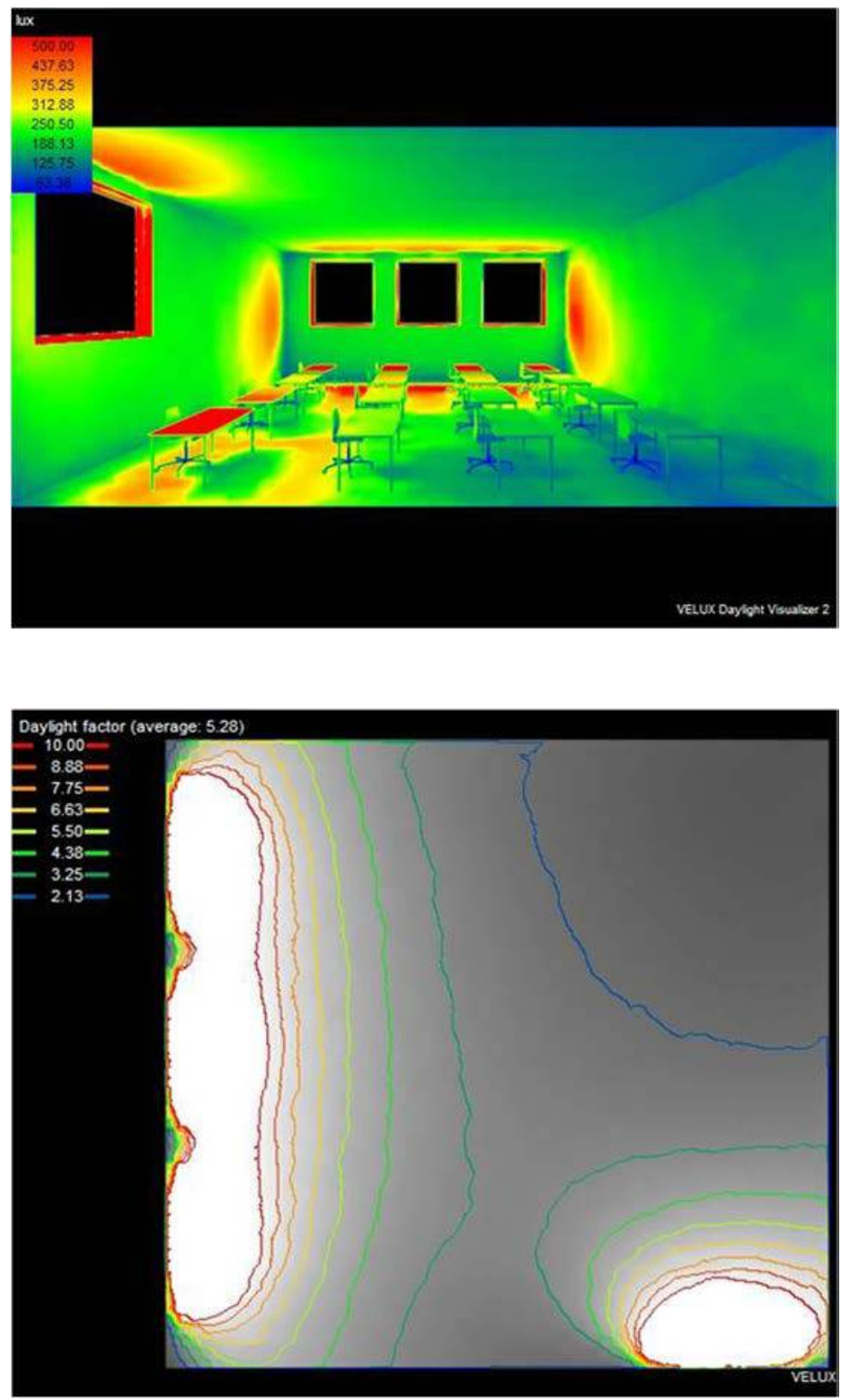

decreases as the height of the window above the floor is increased. However, the illumination increases away from the window, giving greater uniformity to the lighting. Thus, the usable depth of the classroom increases. The distance between the windows and lit work areas display effective role on daylighting design of a building. The illumination levels and DF alone are not enough to decide the daylight performance of a space. The illumination uniformity to increase the usable depth plays a significant role in efficiency on daylighting. 


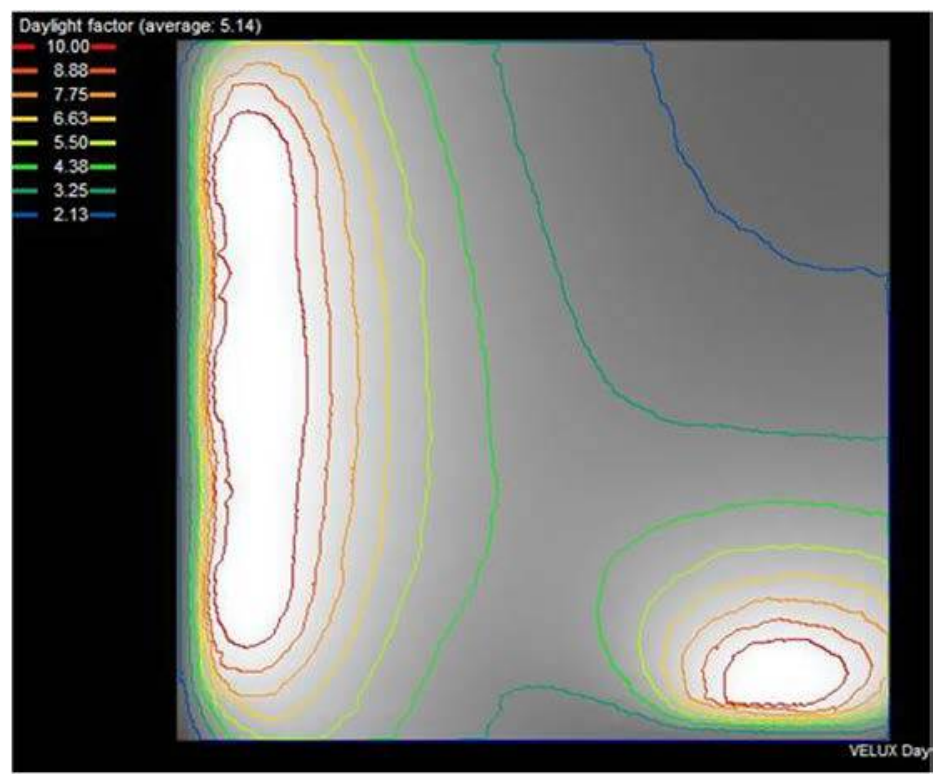

Daylighting performance

Figure 8.

Daylight factor in the case that height of the window above $150 \mathrm{~cm}$ from floor

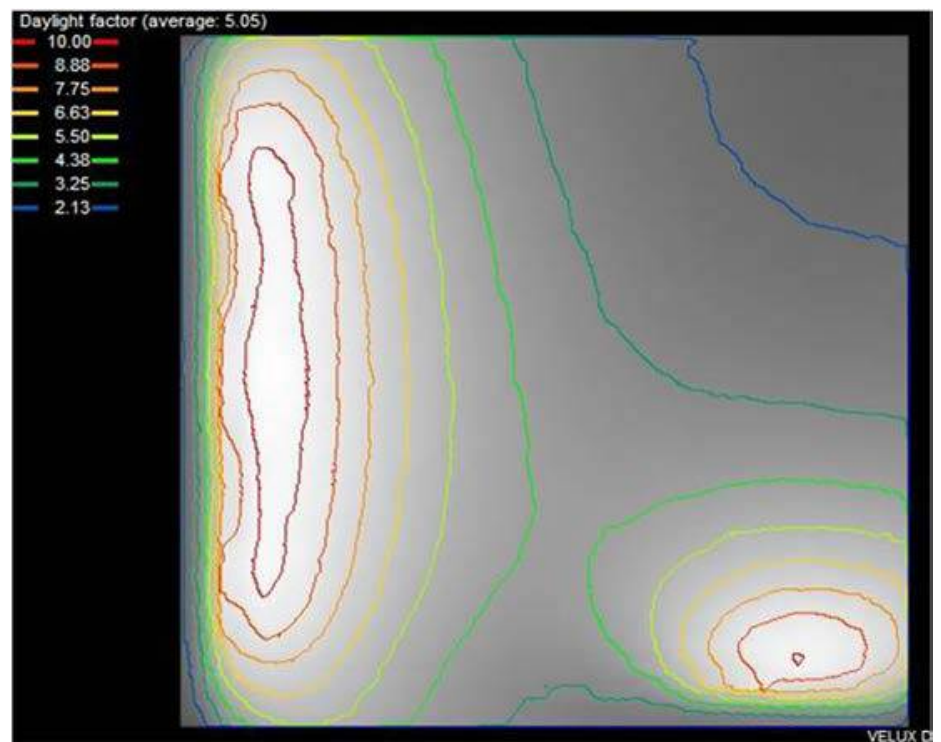

Figure 9.

Daylight factor in the case that height of the window above $160 \mathrm{~cm}$ from floor

Reducing building energy use especially in schools has a significant role on daylighting design. It is necessary to consider the task performed and the interior. Since window design has a significant impact on energy efficiency of a building, the results of the study could be a useful reminder for architects, designers and engineers. 
SS

31,2

136

\section{References}

Aybar, U. (2003), “Ankara MESA Yonca Evler Sitesinin Doğal Aydınlatma açısından incelenmesi”, Gazi Üniv. Müh. Mim. Fak. Der, Vol. 18 No. 1, pp. 45-56.

Balocco, C. and Calzolari, R. (2008), "Natural light design for an ancient building: a case study", Journal of Cultural Heritage, Vol. 9 No. 2, pp. 172-178.

BS 8206-2 (2008), "British Standard", Lighting for buildings. Part 2: Code of practice for daylighting.

British Standards Institution (BSI) (1992), BSI Standards Catalogue, BSI, London.

Building Bulletin 90 (1999), Lighting Design for Schools, Architects and Building Branch, The Stationery Office, London.

Buildings Department, HKSAR (2005), Lighting and Ventilation Requirements PerformanceBased Approach, Practice Note for Authorized Persons and Registered Structural Engineers PNAP278, The Government of the Hong Kong Special Administrative Region, Hong Kong.

BREEAM (2008), BRE Environmental \& Sustainability Standard, BES 5056, issue 2.0, BREEAM, London.

Chartered Institution of Building Services Engineers (CIBSE) (2006), Code for Lighting, Guide A, 7th ed., CIBSE, London.

Cheung, H.D. and Chung, T.M. (2008), "A study on subjective preference to daylit residential indoor environment using conjoint analysis", Building and Environment, Vol. 43 No. 12, pp. 2101-2111.

Commission Internationale de l'Eclairage (CIE) (1970), "Daylight”, technical report, CIE.

CLEAR (2012), "Comfortable low energy ARchitecture" available at: www.new-learn.info/ packages/clear/visual/daylight/index.html (accessed September 10, 2012).

Collins, B.L. (1975), Windows and People: A Literature Survey. Psychological Reaction to Environments With and Without Windows, US Dept. of Commerce, Washington, DC.

Doulos, L., Tsangrassoulis, A. and Topalis, F. (2008), "Quantifying energy savings in daylight responsive systems: the role of dimming electronic ballasts", Energy and Buildings, Vol. 40, pp. 36-50.

Enarun, D. and Littlefair, P. (1995), "Luminance models for overcast skies: assessment using measured data", Lighting Research and Technologv Vol. 27 No. 1, pp. 53-58.

Figueiro, M.G., Stevens, R.G. and Rea, A.C. (2004), "Daylight and productivity", Proceedings of the Fifth International LRD Lighting Research Symposium, available at: http:// eec.ucdavis.edu/ACEEE/2002/pdfs/panel08/06_15.pdf (accessed February 24, 2010).

Fontoynont, M. and Berrutto, V. (1997), "Daylighting performance of buildings: monitoring procedure”, Right Light, Vol. 2 No. 4, pp. 119-127.

Freewan, A.A.Y. (2011), "Improving thermal performance of offices in JUST using fixed shading devices”, World Renewable Energy Congress in Sweden, May 8-13, Linköping.

Galasiu, A.D. and Veitch, J.A. (2006), "Occupant preferences and satisfaction with the luminous environment and control systems in daylit offices: a literature review", Energy and Buildings, Vol. 38 No. 7, pp. 728-742.

Ghisi, E. and Tinker, J.A. (2005), "An ideal window area concept for energy efficient integration of daylight and artificial light in buildings", Building and Environment, Vol. 40 No. 1, pp. 51-61.

Gueymard, C.A. and duPont, W.C. (2009), "Spectral effects on the transmittance, solar heat gain, and performance rating of glazing systems", Solar Energy, Vol. 83 No. 6, pp. 940-953.

Ho, M.C., Chiang, C.M., Chou, P.C., Chang, K.F. and Lee, C.Y. (2008), "Optimal sun-shading design for enhanced daylight illumination of subtropical classrooms", Energy and Buildings, Vol. 40, pp. 1844-1855. 
Hong Kong Government (1997), Laws of Hong Kong Chapter 123 Building (Planning) Regulations - Lighting and Ventilation, Hong Kong Government, Hong Kong.

Hopkinson, R.G., Petherbridge, P. and Longmore, J. (1966), Daylighting, Heinemann, London.

Illuminating Engineering Society (IES) of North America (1993), Lighting Handbook: Reference and Application, Illuminating Engineering Society of North America, New York, NY.

Illuminating Engineering Society of North America (IESNA) (2011), Lighting Measurement e Spatial Daylight Autonomy, Illuminating Engineering Society of North America, New York, NY.

Ihm, P., Nemri, A. and Krarti, M. (2009), "Estimation of lighting energy savings from daylighting", Building and Environment, Vol. 44 No. 3, pp. 509-514.

Jenkins, D.P., Peacock, A.D. and Banfill, P.F.G. (2009), "Will future low-carbon school in the UK have an overheating problem?", Building and Environment, Vol. 44, pp. 490-501.

Keighley, E.C. (1973), "Visual requirements and reduced fenestration in offices: a study of multiple apertures and window area”, Building Science, Vol. 8 No. 4, pp. 321-331.

Kim, G., Lim, H.S., Lim, T.S., Schaefer, L. and Kim, J.T. (2012), “Comparative advantage of an exterior shading device in thermal performance for residential buildings", Energy and Buildings, Vol. 46, pp. 105-111.

Lee, E.S. and Selkowitz, S.E. (2005), "The New York Times headquarters daylighting mockup: monitored performance of the daylighting control system", Energy and Buildings, Vol. 38 No. 7, pp. 914-929.

Lee, W., Jung, H.J., Park, J.Y., Lee, J.B. and Yoon, Y. (2013), "Optimization of building window system in Asian regions by analyzing solar heat gain and daylighting elements", Renewable Energy, Vol. 50, pp. 522-531 (in press).

Li, D.H.W. (2010), “A review of daylight illuminance determinations and energy implications”, Applied Energy, Vol. 87 No. 7, pp. 2109-2118.

Li, D.H.W., Lau, C.C.S. and Lam, J.C. (2004), "Overcast sky conditions and luminance distribution in Hong Kong”, Building and Environment, Vol. 39 No. 1, pp. 101-108.

Li, D.H.W. and Cheung, G.H.W. (2006), “Average daylight factor for the 15 CIE standard skies”, Lighting Research and Technology, Vol. 38 No. 2, pp. 137-152.

Li, D.H.W. and Tang, H.L. (2008), "Standard skies classification in Hong Kong", Lournal of Atmospheric and Solar-Terrestrial Phvsics, Vol. 70 No. 9, pp. 1222-1230.

Li, D.H.W., Cheung, G.H.W. and Lau, C.C.S. (2006), "A simplified procedure for determining indoor daylight illuminance using daylight coefficient concept”, Building and Environment, Vol. 41 No. 5, pp. 578-589.

Lim, Y.W., Kandar, M.Z., Ahmad, M.H., Ossen, D.R. and Abdullah, A.M. (2012), "Building façade design for daylighting quality in typical government office building", Building and Environment, Vol. 57, pp. 194-204.

Longmore, J. (1975), “Daylighting: a current view”, Light and Lighting, Vol. 68 No. 3, pp. 113-119.

Loutzenhiser, P.G., Maxwell, G.M. and Manz, H. (2007), "An empirical validation of the daylighting algorithms and associated interactions in building simulation programs using various shading devices and windows", Energy Vol. 32 No. 10, pp. 1855-1870.

Manz, H. and Menti, U. (2012), "Energy performance of glazings in European climates", Renewable Energy, Vol. 37 No. 1, pp. 226-232.

Mardaljevic, J., Heschong, L. and Lee, E. (2009), "Daylight metrics and energy savings", Lighting Research and Technology, Vol. 41 No. 3, pp. 261-283.

Mardaljevic, J., Andersen, M., Roy, N. and Christoffersen, J. (2011), "Daylighting metrics for residential buildings", Proceedings of the 27th Session of the Commission International de l'Eclairage, Sun City, July 11-15 (CIE 197:2011, Vol. 1, Part 1, pp. 93-111), Vienna. 
SS

31,2

138
Nabil, A. and Mardaljevic, J. (2005), "Useful daylight illuminance: a new paradigm to access daylight in buildings", Lighting Research \& Technology, Vol. 37 No. 1, pp. 41-59.

Ne'eman, E. and Hopkinson, R.G. (1970), "Critical minimum acceptable window size: a study of window design and provision of a view", Lighting Research and Technology, Vol. 2 No. 1, pp. 17-27.

Perez, R., Ineichen, P., Seals, R., Michalsky, J. and Stewart, R. (1990), "Modeling daylight availability and irradiance components from direct and global irradiance", Solar Energv Vol. 44, pp. 271-289.

Pyonchan, I., Abderrezek, N. and Moncef, K. (2009), "Estimation of lighting energy savings from daylighting", Building and Environment, Vol. 44, pp. 509-514.

Ramos, G. and Ghisi, E. (2010), "Analysis of daylight calculated using the EnergyPlus programme", Renewable and Sustainable Energy Reviews, Vol. 14 No. 7, pp. 1948-1958.

Reinhart, C., Mardaljevic, J. and Rogers, Z. (2006), "Dynamic daylight performance metrics for sustainable building design", Leukos, Vol. 3 No. 1, pp. 1-20.

Reinhart, C.F. and Weissman, D.A. (2012), "The daylit area-correlating architectural student assessments with current and emerging daylight availability metrics", Building and Environment, Vol. 50, pp. 155-164.

Singh, M.C. and Garg, S.N. (2010), "Illuminance estimation and daylighting energy savings for Indian regions”, Renewable Energv Vol. 35, pp. 703-711.

Stegou, S.A., Antonopoulos, K., Angelopoulou, C. and Kotsiovelos, G. (2007), "The impact of glazing on energy consumption and comfort", Energy Conversion and Management, Vol. 48, pp. 2844-2852.

Tíba, C. and Leal, S.S. (2012), "Measuring and modelling illuminance in the semi-arid Northeast of Brazil", Renewable Energy, Vol. 48, pp. 464-472.

US Department of Energy (2010), Guide to EnergyEfficient Lighting, DOE, Washington, DC.

USGBC, LEED-NC (2009), "Leadership in energy and environmental design version 3.0", available at: www.usgbc.org/LEED/ (accessed August 25, 2012).

Zain, A., Sopian, K., Othman, M.Y.H. and Zainol, A. (2002), "The availability of daylight from tropical skies: a case study of Malaysia”, Renewable Energy, Vol. 25, pp. 21-30.

\section{Corresponding author}

Tuğba İnan can be contacted at: tugbainan85@gmail.com 